AFRREV, VOL. 9(2), S/NO 37, APRIL, $2015 \mid 1$

African Research Review

An International Multidisciplinary Journal, Ethiopia

Vol. 9(2), Serial No. 37, April, 2015:1-12

ISSN 1994-9057 (Print) ISSN 2070-0083 (Online)

DOI: http://dx.doi.org/10.4314/afrrev.v9i2.1

\title{
The Leadership Role of a Musicologist in the 21st Century Africa
}

\author{
Nwobu, Stella N. \\ Department of Music \\ Chukwuemeka Odumegwu Ojukwu University \\ Telephone: 08030917390, 09094142870 \\ E-mail: nadistel@yahoo.com
}

\begin{abstract}
In this 21 st Century Africa, most music of today -the hip hop, rap, dub-step etc are inappropriate and have foul language. They are not leading people to the right parts. Critical evaluations of such music show that they are pointless (music without meaning- bad songs, bad vocal, poor message and so on). Our perception of music and appreciation today is not based upon real musical worth but rather upon heavy commercial marketing which often mislead critical evaluation of music in print, radio, and television media sources. Definitely bad music is produced not by musicologists that are competent both in theory and practice but rather by untrained/quack musicians. This paper examines the leadership role of musicologist in the $21^{\text {st }}$ century Africa and was discovered that musicologist (composer, historian, music theorist, performer and so on) as a valid member of a society, a societal conscience and watchdog performs tremendous leadership role in all sphere of life including political system (in government). He functions as a social critic, a historian, a social witness and recorder of events. He functions in social mobilization, in social stability, in social control, and in external affairs. As an oracle of the society, he
\end{abstract}

Copyright (C) IAARR, 2015: www.afrrevjo.net Indexed African Journals Online: www.ajol.info 
directs and redirects the mind of people, leading people aright. It is hoped that this paper would open people's minds and souls to follow the right parts through right music which when evaluated, will be music that have immense worth for our African society. It recommends that the untrained musicians should use their musical power in the right context and not passing jargons and pointless music across.

Key words: Musicologist, Leadership, Role, Music

\section{Introduction}

In every culture, music is intricately interwoven with the lives and beliefs of its people. It serves different functions in different societies though the basic ones were outlined by Merriam (1964) as "emotional expression, aesthetic enjoyment, entertainment, communication, symbolic representation, physical responses, enforcing conformity to social norms, contribution to the continuity and stability of culture and contribution to the integration of the society". People have always found music significant in their lives, whether for enjoyment in listening, the emotional response, performing or creating.

There are many things in music to which one can listen and bring attention to. One can be mindful of the melodies or themes, the harmony, the dancing or relaxed rhythms, the colour of the sounds, the activity of a piece, how the sounds are produced or how they all relate to one another. Music has immense worth. People learn many important and necessary values for life as it enhances their mind, their expressive ability and a host of other qualities. Vidal (2012, p.80) noted that "music plays an important role in regulating, sustaining and preserving the various institutions of the societies". He further described of it as "an instrument of discipline and social control through which a curfew may be improved on the entire society and the judicial execution of condemned criminals carried out. Music in Africa is a way of life and not a form of entertainment. It is more than just aesthetics expression. It is used in vital aspects of life. Music is an integral part of the African Culture, with various ceremonies being preceded by some sort of music. Music is useful to the society. It guides, reflects the society, records the society and watchdog the society.

There are different types of music which can generally be grouped into three categories, namely; vocal, instrumental and dance. Dance music is designed for body expression. It always involves the voice, instruments and costumes. Instrumental music is the type of music that does not engross singing, or ratter music which utilizes singing, but does not feature it prominently. It is any music from any type of

Copyright (C) IAARR, 2015: www.afrrevjo.net Indexed African Journals Online: www.ajol.info 
instrument other than the human voice. Vocal music is a genre of music performed by one or more singers. It involves singing of songs, anthems, and so on. Vocal music is performed with instrumental accompaniment. When performed without instrumental accompaniment, it is called a cappella. In vocal music, singing provides the main focus of the piece. Vocal music typically features sung words called lyrics or song text which usually carries the message of the song.

\section{The Concept of Musicology}

Musicology, a derivative from the Greek words - mousike and logia (music and study of') is according to Wikipedia - "the scholarly analysis and research focused study of music". It is the erudite and aim study of music of all types from all approaches. Ipere (2002) states that musicology is:

The study of the history, theory and physics of music, the field which involves the scholarly and objective study of music of all types and from all approaches has actually given the lion's share of its attention to the music of Western urban civilization, the music of the European written tradition (p. 47).

A systematic knowledge or a systemic study of music is defined as musicology according to Grove's Dictionary of music which is called in French language "musicologie" and in the Italian language "musicologia." Vidal (2012) described it as "when one is engaged in the activity of reducing the music of one's area to a system, or systematizing knowledge of the music of one's area as practiced by ones musicians, such person is "musicologising". Musicology is the academic and scientific study of music that covers all types of music from all over the world; from art music to folk songs, from European music to non-western music. Musicology also includes - the study of various musical forms and the evolvement of music notation, the study of different musical instruments, the study of the elements of music and music theory, the study of composers, musicians, and performers, the study of how music is perceived and how it influence or attracts a listener.

The parent disciplines of musicology include history, culture studies, philosophy, aesthetic and semiotics, ethnology and cultural anthropology, archaeology and prehistory, psychology and sociology, physiology and neuroscience, acoustics and psycho-acoustics, and computer/information sciences and mathematics. Musicology also has two central, practically oriented sub disciplines with no parent 
discipline: performance practice and research, and the theory, analysis and composition of music.

Musicology is divided into 3 broad domains namely -Historical musicology, Systematic musicology and applied musicology. Systematic musicology consists more or less independent music studies which include Music Acoustic, Physiology, Psychology, Aesthetics, Sociology, Pedagogy, Theory, Physiology, Psychology, Sociology, Philosophy and Computing. Historical musicology studies the composition, performance, reception and criticisms of music over time. It is concerned for example with a composer's life and works, the developments of styles and genre, the social function of music for a particular group of people, (e.g. court music) or modes of performance at a particular place and time. These three broad domains were sub-divided into sections which include: - Science of instrument, Iconography Science of sources of authority, Terminology, Music criticism and others.

\section{Musician, a Musicologist or Vice Versa}

Musicians are very useful members of the society that contribute to the functioning of the societal activities. Any person, who is involved with music making whether as a composer, a performer, dancer, instrumentalist etc, is regarded as a musician in African society. Ipere (2002) remarked that:

a musician is the music maker. He is the composer - the originator of any piece of music, be it vocal or instrumental. He is an artistic interpreter of other people's compositions through his performances. The singer, the instrumentalist, the choral or orchestral conductor or director comes into this category (p.47).

Ibekwe (2010) noted that "musicians are great thinkers, or better described as philosophers who take cognizance of the events of the past, live up to the expectation of the present, and equip the mind for the future" (p. 33). Okafor (2005) identifies three different categories of musicians. They are the academics - western trained musician, who are trained in all the rudiments and theories of the art; who may not be as naturally gifted in performance. The second category is the gifted, excellent performers who through their talents release music which the society accepts though academically, they may not be trained. Through their music, they evoke, move, express and inspire the audience. The third category is the musicians who perform music as their total profession. He further described them as the "popular musicians 
whose music moves audiences and markets around the world". People trained in all the rudiments and theories of the art as described by Okafor (2005) are the musicologists.

In African society, a musicologist is equally described as a musician. Ipere (2002:47) pointed out that "the musicologist is a musician. In other words, anybody who is as involved in any branch of music as to make a career of it is a musician". Nwamara (2013) opines that:

Musicologists are musicians who underwent a formal musical training in the tertiary institutions and are either teaching music and/or performing music. They are formally trained musicians who spent years in higher institutions and acquired knowledge and skills involved in composition; interpretation, performance and writing of music" (p.156).

A musicologist is a person who studied music. He is an accomplished musician with a deep understanding of his art, who looks at music from different angles. A person who studied music theory is a music theorist who attempts to explain the techniques composers use by establishing rules and patterns. A historical musicologist may look at how different forms of music arose, when new instruments entered common usage and how music has influenced cultures throughout history. A musicologist who focuses on music from other cultures is often known as ethnomusicologist. This type of musicologist works in the field documenting such music along with folktales and information about musical instruments.

In as much as musicologists are musicians, they are special type. All musicologists are musicians but not all musicians are musicologists. Vidal (2012) opines that:

the dundun drummer, the ikoro player as well as the kundund striker and the komo plucker are musicians not musicologist for though they have knowledge about their music and use such knowledge in the act of creating a new form and expressing themselves musically, such knowledge is still to be studied and reduced to a system (p. 214)

Nwamara (2013:156) described them as "professionals with creative and innovative ideas who can represent and preserve sounds using notations and express their philosophy of music and education by demonstrating contemporary education 
techniques in teaching music" (p. 156). Idolor (2002) distinguished between the word musician and musicologist with this expression:

The word musician has become synonymous with stage practitioners (artistes) who entertain or carry out other extra-musical responsibilities as demanded by the society, irrespective of their training. Musicologists on the other hand, receive substantial formal music education and are pre-occupied with its studying application of research outcomes and dissemination of ideas to people (p. 61)

He who would be a successful musician should be ready according to Onyeji (2002:43) to "study and understand many other disciplines such as history, geography, mathematics, physics, drama, architecture, fine arts, philosophy, politics, religion, computer, technology, literature and aesthelics for they are all related music". For such, it is only musicologist who can meet up with such requirements and that is why the end product of a musicologist (music) when critically evaluated show real musical worth - meaningful/good lyrics, good sound, good vocal, good tone, good instrumental, written and sung by people who have experienced what they are singing and just all around commendable. This is an extract from the lyrics of 'Pant No N'iro' by a musician FLAVOUR, one of the Nigerian musicians that sing corrupt songs.

Pant no n'iro (3x) Onye nwe pant no n'iro

The way you shake it, the way you break it

I can't take any longer

The way you pull it down makes me go stronger

If you give me chance, I will make it right.

I will take you higher, stop playing around, stop getting wiser,

Am a superman, Nigerian, the one on fire.

I go do many many things to you.

We will dance all night, then we take it off.

Baby straight to the house, we will take the shower

and then we off the light, we go carry dey go.

This is another extract from the lyrics of Ara dara ada by Flavour: 
Ara dara ada adago, ife bara aba abago

Ukwu nwanyi a na mghori

Ha buru gbago, ha eburu gbada

Baby baby fire dey go

All boys don kolo

And they want some kporokolokpolomkpo

She come dey piompiompiompiompiom

This is an extract from the lyrics of Anambra State Anthem by a musicologist - Prof. Dan. C. C. Agu.

Anambra State; am happy to be your child

Am happy to be in you, am happy to be associated with all your progress.

May God direct, protect and guide all your good intentions.

What shall I do for the progress of my State?

What shall I offer for the growth of my State?

Handwork, honesty, diligence, efficiency;

all these are what I owe my State;

my beautiful home, my pride forever.

Critical evaluation of the texts of this song shows that this is a patriotic song. Agu used his musical values to express and communicate his feelings and thoughts about his state Anambra. Ubani (2013) remembered that "the socio-political and cultural life of his people made him preach the spirit of good citizenship to Anambrarians.. Evaluations of the texts of pant no n'iro and ara dara ada by Flavour show pointless/meaningless/corrupt lyrics. Ipere (2002:50) pointed out that "the musician is by nature a moralist and great preacher. What did Flavour as a great preacher preached with these music? 
AFRREV, VOL. 9(2), S/NO 37, APRIL, $2015 \mid 8$

\section{THE NIGERIAN NATIONAL ANTHEM}

BEN. ODLASE 1978
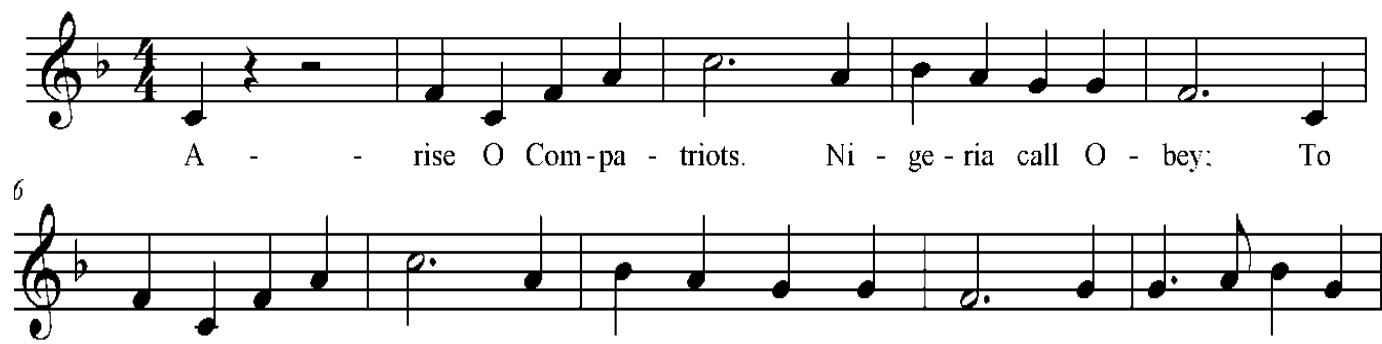

Serve our fa-ther Land. With love, and Strength, and faith; The la - bour of our

II

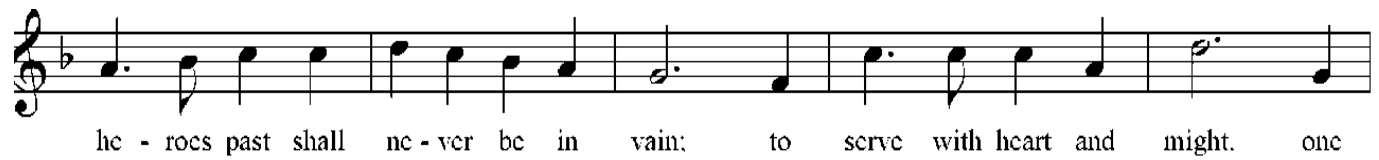

s.

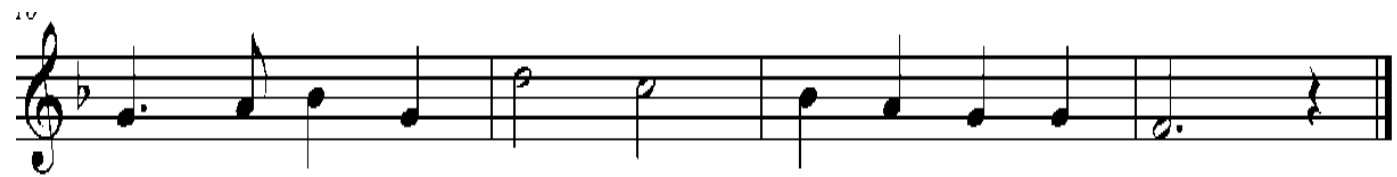

na - lion bound in lie - dom, peace and $\mathrm{ll}$ - ni - ty

Oh God of creation, direct our noble cause

Guide our leaders' right

Help our youth the truth to know,

In love and honesty to grow,

And living just and true;

Great lofty heights attain

To build a nation where peace and justice shall reign

Ben Odiase designed this music to unite and express the unity of people, preaching peace, integration, personal commitment and patriotism to our nation, Nigeria. 
Good/Great musicians should through their works preach sermon that will touch on every subject in the world.

\section{The Leadership Role of a Musicologist}

Music is certainly a true companion of humans as it works quite efficiently in mirroring behaviors, needs, and emotions. Music has been an efficient carrier of information that has been used for centuries as a vehicle to communicate and teach; because it effectively taps into memory. Music has many functions. It is the social, emotional and cognitions vehicle of society, reflecting the imprint of our present identity and the always - evolving identity.

Without musician, there is no way to pressure music and to have music performed and heard by people. Musicians especially musicologists devote most of their time creating music, making use of the best of their talents, the best of their techniques, the best of their imagination, the best of their experience to make music. They create and perform music that enhanced and manifest emotion, used as a carrier of information, stimulate the minds of a society and energize their spirit.

A musician is a relevant and necessary institution in the society who uses the medium in which he is proficient to express the societal values in a language the people understand and appreciate. Nzewi (1991) asserted that:

The musician remains to a large extent the soul and conscience of his entire community. He does not necessarily humour the whims of vain individuals in the society. His integrity as a musician is important to him and is appropriately recognized and respected by his community or event music user (p.148).

Okafor (2005) said that "the musician of any community poured out some of the values of the people. They provided quotable quotes and even reference materials. They gave the signposts, which guided the people on their pilgrimage of life" (p. 280). Okafor (2009) quotes that "musicians do not merely entertain with their music but use it as a vehicle for social commentaries, education and for reflecting and influencing the political life of Africa" (p. 93). Musicians especially musicologists in African society are not just entertainers; they play many roles in the society including leadership role.

Leadership is a key skill that every musicologist needs to master and use item to provide direction for their society. In terms of leadership role, the musicologist 
communicates to the people, creates awareness, mobilizes people, directs and redirects the mind of people to follow the right parts.

Musicologist (composer, performer, theorist, conductor, historian, etc) instruct the society with his music. He disseminate information, he organizes, promotes and educate the people. Information of historical and philosophical importance are preserved in his music and pass to people. Oguno (2010) opines that "musician has a role in the society, which is to instruct while entertaining. Songs are composed according to the social-cultural and political needs of the society". In the traditional African society as Okafor (2005:6) puts it, "the musician is an educator. Many of our social comments, moral codes and guides are couched in music and songs. He has a role; he has a place; he has his privileges as a full member of the society". The musicologists make social commentaries with his music. The society's system of laws, social norms and behavioral pattern and the maintenance of these laws and orders are recognized and exposed publicly through music, composed and performed by musicologists. Okafor (2005) further pointed out that:

the musician has a role as a keeper of public conscience and as a man who has his hands on the social lever. He guides the society, drawing of course from the collective wisdom and pool of knowledge and proverbs of his people. He is expected to inform, correct, counsel, praise as well as entertain the community where he belongs (p.6)

A musicologist performs leadership role of a social critic. He uses his music which is one of society's weapons of offence and defence to criticize. As a true voice of the people who says what everybody is talking about, "he looks critically at what happens in his society - at the conduct and foibles of men, at the person's behind the personalities and create a song with the objective of social control" (Okafor \& Okafor 2009, p. 38). The musicologist bases his texts on themes specifically designed to motivate society, or to warn, correct or impinge on social or political deviations. According to Okafor (2009), "the musician with the right words and the right composition is always a strong favourite and he gets his way" (p. 87).

$\mathrm{He}$ also helps in instilling patriotic and nationalistic feelings in society by appealing for a positive change (Okafor \& Okafor 2009:53). Examining the lyrics of Anambra State Anthem by Prof. Dan C. C. Agu (a musicologist) and Nigerian National Anthem by Ben Odiase, one sees how both with those patriotic songs, perform a leadership roles of communication, direction, mobilization and redirection 
of the minds of people towards the right paths. Musicologists produce music that is generous, never discriminating; rather a friend of every single human on earth, regardless of sex, age, social status, preference or diagnosis.

\section{Conclusion}

Music serves different functions in different societies but without musicians, there will be no music, no performance of it, and no preservation as well. Musicians especially musicologists are valid members of African society where they perform may functions including leadership role. As leaders in the society, they through their music, direct, educate, mobilize, instigate, criticize and redirect the minds of people to move towards the right paths. They produce good music good melody, good instrumentation, meaningful lyrics, good sound, good tones; good vocal, written and sung by people who have experience what they are singing. In terms of leadership role, through his music, he disseminate information, he educates, criticizes, mobilizes, make social commentaries, directs and redirects the mind of people towards the rights paths. His music, comprising all elements of music if critically evaluated show real musical worth.

\section{References}

Ibekwe, E. U. (2010). Musicians and the Philosophical Dimension of African Man. Awka Journal of Research in Music and the Arts (AJRMA) 7, 33-45.

Idolor, E. (2002). The theorist and the performer in musical practice. In Idolor, E. (ed.) Music in Africa: Facts and illusions. pp. 54-63. Ibadan: Stirling-Horden.

Ipere, D. (2002). Music and Musicians in the Broardcasting Industry. In Idolor, E. (ed.) Music in Africa: Facts and illusions. pp. 46-53. Ibadan: StirlingHorden.

Merriam, A.P. (1964). The Anthropology of Music. Evanston: Northwestern Univ. Press.

Nwamara, A. (2013). Practicing what you preach: The place of Nigerian musicologists in popular music performance. Journal of the Association of Nigerian Musicologists (JANIM). 7, pp. 150-160.

Nzewi, M. (1991). Musical practice and creativity: An African traditional perspective. Germany: Iwalewa-Haus, University of Bayreuth. 
Ogidan, P. D. (2012). Music as political activism: A case study of Fela Anikulapo Kuti's afro beat. An Unpublished B.Sc. Project Submitted to the Department of Political Science, Faculty of Social Science, University of Lagos.

Okafor, R. C. (2005). Music in Nigerian society. Enugu: New Generation Books

Okafor \& Okafor (2009). Music and National development in Nigeria. Enugu: New Generation Books.

Olaniyan, O. (2002). Music as a Career: Challenges and Prospects in a Changing African Society. In E. Idolor (ed.). Music in Africa. Facts and Illusions Pp. 38 -45. Ibadan: Stirling-Horden.

Onuora-Oguno, C. N. (2010). The Musician as a Watch Dog in a Democracy: Echoes from Songs of Patty Obasi and Ozoemene Nsugbe. Awka Journal of Research in Music and the Arts (AJRMA) 7, 154-160.

Onyeji C. (2002). Popular music: Facts about the music and musicians. In Idolor, E. (ed.) Music in Africa: Facts and illusions. Pp. 24 -37. Ibadan: StirlingHorden.

Ubani, A. (2009). Performance of Three Artworks of Dan. C. C. Agu: A Contemporary Art Composer. Unpublished Ph.D. Research Seminars, Delta State University, Abraka.

Vidal, A.O. (2012). Selected topics on Nigerian music. Ile-Ife: Obafemi Awolowo University Press.

Wikipedia, (2013). What is musicology? Retrieved November 16, 2014, from http://en.wikipedia.org/wiki/musicology. 